\title{
AN ANALYSIS ON THE FACTORS INFLUENCING THE SECOND LANGUANGE ACQUISITION (STUDENTS' ENGLISH LEARNING ACHIEVEMENT) OF THE USHULUDDIN, ADAB AND DA'WAH STUDENTS
}

\author{
Wardah \\ A Lecturer of Ushuluddin, Adab and Dakwah Faculty (FUAD) of IAIN Pontianak \\ Email: wardahhanafiabid@yahoo.com
}

\begin{abstract}
This research was conducted for factors (internal and external) which influences students' second language acquisition (students' learning achievement). This research has investigated the effect relation of the factors on students' learning achievement and the factors which influence the students' learning achievement and the factors that comes from the students that influencing the students' second language acquisition (learning achievement).This research use quantitative research. This research conducted in Ushuludddin, Adab and Da'wah Faculty, especially for 5 majors. The sample of this research about 100 students. The data in this research were collected by documentation technique and questionnaire technique. In analyzing the data, the researcher using Multiple Regression Analysis (SPSS 17), T test, F test, and Coefficient Determination $\left(R^{2}\right)$. Motivation, personal practice, study habits, and input has significant effect to the students' learning achievement. Attitude, social factors and interaction has no significant effect to the students' learning achievement.
\end{abstract}

(Penelitian ini dilakukan untuk mengetahui faktor-faktor (internal dan eksternal) yang mempengaruhi akuisisi bahasa kedua mahasiswa (prestasi belajar mahasiswa). Penelitian ini telah meneliti hubungan pengaruh antara faktor-faktor prestasi belajar mahasiswa dan faktorfaktor yang mempengaruhi prestasi belajar mahasiswa, serta faktor-faktor yang berasal dari mahasiswa yang mempengaruhi akuisisi bahasa tersebut. Penelitian ini menggunakan pendekatan kuantitatif. Penelitian ini dilakukan di Ushuludddin, Adab dan Fakultas Dakwah, khususnya pada 5 jurusan. Sampel penelitian ini sekitar 100 mahasiswa. Data dalam penelitian ini dikumpulkan dengan teknik dokumentasi dan teknik kuesioner. Dalam menganalisis data, peneliti menggunakan Analisis Regresi Berganda (SPSS 17), uji T, uji F, dan Koefisien Determinasi (R2). Motivasi, praktik pribadi, kebiasaan belajar, dan masukan memiliki pengaruh yang signifikan terhadap pencapaian belajar mahasiswa. Sikap, faktor sosial dan interaksi tidak berpengaruh signifikan terhadap prestasi belajar mahasiswa).

Keywords: Internal and external factors, students' learning achievement

\section{Research Background}

Second language can refer to any language that is learned to the mother tongue. In Indonesia, second language can be called as foreign language. In this case, the researcher emphasizes to the English as the second language. English is one of language that must be learned in Islamic 
State Institute of Pontianak, especially in Ushuluddin, Adab and Dakwah IAIN Pontianak. Second language acquisition (SLA) can be defined as the way in which people learn a language other than their mother tongue, inside or outside of classroom.

SLA has not focused on these communicative aspects of language development but on the formal features of language that linguists have traditionally concentrated on. One of the goals of SLA, is description of second language acquisition. Another is explanation, identifying the factors that account the learners acquire a second language in the way they do. Language acquisition is very similar to the process of somenone in acquiring first and second language. There are different ways to acquire the second language. It can be in a formal way as in a classroom enviroment or informal way such as when the learner picks up the language by being culturally active participant of the society.

To some degree, some factors can influence learners' achievement in second language acquisition, mainly in their. In learning second language, the students must learn to acquire knowledge through the English. The academic achievement will show the outcome of learning process.
That is called English learning achievement. Second language learning success can be showed by the result of the final score in students' English subject.

Every student who runs the learning process must want a good achievement in learning that they do. So also students of Ushuluddin, Adab and Da'wah Faculty want have a good achievement as well. Achievement is often identified with high Achievement Index (IP) and a good score of each course. From preliminary survey, the results of interviews with students it can be concluded that the learning achievement shown by IP and score was obtained because there are several factors that influence, both the factor of the students (internal factors) and external factors from the students (external factors). Both internal factors and external factors cannot be separated from the learning process.

In this research, the researcher focused on the analysis of factors that influencing students' second language acquisition result as achievement. Based on the researcher's informal observation previously towards the students in Ushuluddin, Adab and Dakwah Faculty, there are some circumtances where the students with good score in final examination do not have good study 
habits. Vice versa, students with good personal practice in the class eventually do not end with good score on their study result sheet in final examination. Some facts stimulated the reseracher's curiosity to do the further observation and research, that was, finding out what are truly factors which influence the students' second language acquisition showed by their achievement. By knowing the factors, improving the quality of the influential factors are wide opened.

Therefore, the finding of this research can help the lecturers to create innovative materials and strategies in teaching English in the class. Besides, the researcher wants to take part in improving the quality of the the students in 5 majors of Ushuluddin, Adab and Dakwah Faculty, Islamic State Institute of Pontianak. The students, the lecturers, and other related people will have acknowledgment to take better step in providing the factors which influence the students' achievement. The students will take role in improving their factors, the lecturers can take role in refreshing other factors, the rest, the related people who care about students' improvement can support them by creating better atmosphere for learning. That's why the ereseracher considers this research is very important to conduct, that is as one of efforts to contribute solution for better quality output students of Ushuluddin, Adab and Dakwah Faculty,especially, and Islamic State Institute of Pontianak generally.

Based on the above description, the researcher is interested to conduct research entitled "An Analysis on the Factors Influencing the Second Language Acquisition of Students in Ushuluddin, Adab and Dakwah Faculty". The goal is to determine the factors that influence students' achievement. The researcher hope that after knowing the factors that influence students' achievement, both students and lectures can improve students achievement so as to improve the quality of human resources generated especially Ushuluddin, Adab and Da'wah Faculty, Islamic State Institute of Pontianak.

\section{Research Problem}

In order to make this research consistent with the topic and based on the backgrounds mentioned above, the research problem is "Does the internal and external factors have significant influence both simultaneously and partially to the second language acquisition (learning achievement) of Ushuluddin, Adab and Da'wah Faculty students, Islamic State Institute of Pontianak? 


\section{Research Purpose}

Based on the spesific problems stated above, the purposes of this research is to determine the effect of internal and external factors both simultaneously and partially to the second language acquisition (learning achievement) of Ushuluddin, Adab and Da'wah Faculty students, Ushuluddin, Adab and Da'wah Faculty students, Islamic State Institute of Pontianak.

\section{Research Hypothesis}

In this research, the researcher formulated the hypothesis into two:

1. The Null Hypothesis

There is no significant effect between the internal factors and external factors on students' learning achievement.

2. The Alternative Hypothesis

There is a significant effect between the internal factors and external factors on students' learning achievement.

\section{Scope of Research}

1. Research Variables

a. Independent Variable

The independent variable are internal factors and external factors.

1) Internal factors are:
a) Motivattion
b) Attitude

c) Personal practice

d) Study habits

2) External factors are:
a) Social factors
b) Input
c) Interaction

b. Dependent Variable

The dependent variable in this research is students' learning achievement.

\section{Research Significance/ Contribution}

Research is a considered activity which aims to make an original contribution to knowledge ${ }^{1}$. Based on that theory, the researcher aware that the most significant point in this research is the contribution to the knowledge by ivestigating activity to discover or revise facts, theories and applications. This research has its orisinality and different context than other reserach. In other words, the contribution of this research to quality in the process and result of second language acquisition. This research can help the lecturers create innovative strategies in teaching English. By knowing the effect relation factors that influence the result of the second language learning process, the lecturers can make good atmosphere in teaching based on the

\footnotetext{
${ }^{1}$ Dawson, 2009. Introduction to Research Methods: A Practical Guide for Anyone Undertaking A Research Project: How To Books.
} 
condition of the students in order to improve the quality of the learning process and the students' achievement.

\section{The Factors Influencing Students'}

\section{English Learning Achievement}

The learning of English as the target language can take on a variety of pattern and involve many factors. Mackey cited in Setiyadi $^{2}$ suggests that there are three main influences that determine the learning, namely linguistic, social, and psychological influences. The factors above are called internal factors, external factors, and psychological factors. These factors include personal motivation, selfesteem and personality, age, attitudes toward the class and the language, study habits, learning environment and language aptitude. Ellis (1985) states the categories of "personal" and "general" factor to explain the factor that can influence learning achievement ${ }^{3}$.

Johnson (2006) divides the factors affecting foreign language study into two different groups: internal factors and external factors. These divisions are not based on whether the features are specific to an individual or to a variety of learners, but rather on what level of control the

${ }^{2}$ Setiyadi, A.B. 2006. Teaching English as A Second Language. Yogyakarta: Graha Ilmu., hlm. 98 .

${ }^{3}$ Ellis, Rod. 1985.Understanding Second Language Acquisition. Oxford: Oxford UP, p 73. learner has on each one. Internal factors come from the students' individuality. Internal factors are the factors which come from students themselves that influence students' achievement of English subject such as motivation, attitude, personal practice, and study habits ${ }^{4}$.

Ellis (1994) explains three factors; they are external factors, internal factors, and individual differences. External factors are the factors or something outside learners that influence the learning process and the goal. The external factors consist of social factors, input, and interaction. External factors can be different for each individual, but their factor is that they are based on circumstances outside of the influence of the learner. External factors may influence learners from learners themselves. However, the internal factors come from themselves 5 .

Students' learning achievement is the level of the students' ability in learning subject. It is followed by changing behavioral which is stated in scoring that has been gained from the result of the certain material. The successfulness of teaching learning that is reflected achievement. So, it is influenced by many

${ }^{4}$ Johnson, B.J. 2006. Foreign Language Learning: An Exploratory Study on the External and Internal Influences Affecting Success. Thesis. Unpublished. Faculty of Baylor University, p. 3.

5 Ellis, Rod. 1994.The Study of Second Language Acquisiton. Oxford: Oxford UP, p. 41. 
factors, there are; internal and external factors. In the following explanation, the internal and external factors will be discussed more.

Learning foreign language requires learners to consider not only the external factors but also internal factors as the factors that come from inside of the learner. Internal factors play a big role in determining English learning achievement. It is increasingly obvious that the internal factors can overtake the external factors in their realm of influence. Even when the externals are at the "perfect position" according to the studies, evidence now shows how the internal factors can alter success.

Johnson (2006) explains that internal factors include those which are determined by the individual learner such as motivation, attitude, personal practice, and study habits. Each of these is an individual component of the student's ability to learn a foreign language, but each component also interacts with the others. When motivation is low, then study habits and attitudes are affected as well. Motivation mostly influenced by the students' belief about what they might be if something is done. Identical to motivation, attitude comes from the students' individual. In the complete research design, motivation, attitude, personal practice and study habits will be discussed ${ }^{6}$.

External factors absolutely affect the English learning achievement. External factors include social factors (home/ family, community, campus, occupation, radio and television), input and interaction. As the learners, they need help and support from everybody outside. Johnson (2008) states the view of scaffolded help, in which help is provided by a more capable individual such as an expert, parent, or an adult native speaker, learner at the same level of second or foreign language proficiency appear quite capable of providing guided support to one another ${ }^{7}$.

Besides, the condition of learners' home, family and community affect the learner in process of learning. The learner spends most of his time in his home. Community gives positive view about the importance of foreign language learning will help the learner learns effectively. Three major factors that influence in the campus are the lecturer, classmates, and class atmosphere. Besides, job prospect is one of the factors that influence the

${ }^{6}$ Johnson, B.J. 2006. Foreign Language Learning: An Exploratory Study on the External and Internal Influences Affecting Success. Thesis. Unpublished. Faculty of Baylor University, p.3.

${ }^{7}$ Johnson, M. 2008. A Philosophy of Second Language Acquisition. London: Yale University Press, p. 120. 
language learner. The students will be more interested in English learning if they know the occupation that they want for the future. Furthermore, electronic media (radio and television) can affect in learning English. Learner who often listens to the radio and watches television will get more input to make him interested and have more spirit to learn English.

\section{Internal Factors}

Learning foreign language requires learners to consider not only the external factors but also internal factors as the factors that come from inside of the learner. Internal factors play a big role in determining English learning achievement. It is increasingly obvious that the internal factors can overtake the external factors in their realm of influence. Even when the externals are at the "perfect position" according to the studies, evidence now shows how the internal factors can alter success.

Johnson (2006) explains that internal factors include those which are determined by the individual learner such as motivation, attitude, personal practice, and study habits. Each of these is an individual component of the student's ability to learn a foreign language, but each component also interacts with the others. When motivation is low, then study habits and attitudes are affected as well. Motivation mostly influenced by the students' belief about what they might be if something is done. Identical to motivation, attitude comes from the students' individual ${ }^{8}$.

\section{English Learning Achievement}

Learning is not all about gaining something by the lecturers or trainings but it can be the things that we learn from our everyday life experiences. It is better to learn from others experiences then to tolerate tough things yourself. Learning is not a single step process. It takes by and by processes to shape itself. Learning something is like keeping it in mind forever, it is not like remembering but to considering it the way it is and the way it can be.

Learning means an attempt to know something which we did not know before. The kinds of change in learning exhibit as a change in behavior and the interference of learning is made by comparing what behavior was possible before the individual was placed in a learning setting and what behavior can be exhibited after learning treatment.

${ }^{8}$ Johnson, B.J. 2006. Foreign Language Learning: An Exploratory Study on the External and Internal Influences Affecting Success. Thesis. Unpublished. Faculty of Baylor University, p. 3. 
Besides, learning is a voluntary act. The desire to learn must come from the students as individual. The students themselves should be freely encouraged, stimulated, or guided to learn any skill. It could not be expected only from the lecturer. There should be a controlled environment with which the lecturer and the students all together must provide. In other words, learning is the changing of behavior in a positive direction to solve practical, economic, social, political, and personal problems encountered by individuals, groups, and communities.

In conclusion, in this research learning is a process of change which occurs in one's behavior through trainings or experiences to achieve a goal. Learning achievement is not always understood in the same meaning. Different experts may define achievement differently. Achievement is the evidence of an obtainable or achievable attempt. The people with a need for achievement seek to accomplish things and to improve their performance. Such students have strong motivation which is aroused by neither a too easy nor a too difficult task. Needs for high achievement become stronger when there is a greater hope to succeed and not to fall from the concerned. Based on the above characteristics a person with a high need of achievement is behavioristically characterized as self confident, competent, learning interested, competitive and future oriented.

In conclusion, learning is a process through which a person attempts to know what he did not know before. As process, learning causes changes. A person with years of education may know himself better than before. By learning, a person may change his behavior as a result of practice and experience. English learning means a process of mastering the aspect of English. The success or failure of English learning is shown by the learners' achievement. It will reflect the learners' proficiency of English. The learners have learnt well if they get good achievement and the learning.

\section{The Relationship between the Internal} and External Factors and Students' English Learning Achievement

As stated by Johnson (2006, the factors affecting foreign language learning are divided into two different kinds: internal and external factors. Internal factors include those which are determined by the individual learner such as motivation, attitude, personal practice, and study habits. Focus on this research design is about internal factors influencing students' 
learning achievement on English subject.

The internal factors in this research are motivation, attitude, personal practice, and study habits ${ }^{9}$.

Motivation is some kind of internal drive that encourages somebody to persuade a course of action, if we perceive a goal (that is something we wish to achieve) and if that goal is sufficiently attractive we will be strongly motivated to do whatever is necessary.

Motivation has been shown to be strongly related to second language achievement. Motivation in second language learning constitutes one of the most fully researched areas of individual differences. The bad effect appears when the learner does not have a motivation. They will not study seriously, because do not have a goal to be reached.

Here, the writer focuses on integrative and instrumental motivation. Integrative motivation has been shown to be strongly related to second language achievement. It combines with instrumental motivation to serve as a powerful predictor of success in formal contexts. Learners with integrative motivation are more active in class and are less likely to drop out. Instrumental

9 Johnson, B.J. 2006. Foreign Language Learning: An Exploratory Study on the External and Internal Influences Affecting Success. Thesis. Unpublished. Faculty of Baylor University, p. 3. motivation, this is generally characterized by the desire to obtain something practical or concrete from the study of a second language ${ }^{10}$. With instrumental motivation the purpose of language acquisition is more utilitarian, such as meeting the requirements for campus or university graduation, applying for a job, requesting higher pay based on language ability, reading technical material, translation work or achieving higher social status. Based on the explanation above, those factors are condition inside and outside learners that are covered by internal and external factors. In this research, the writer obtained the data by using questionnaire and students' achievement. The questionnaire is distributed to the students and they are expected to answer the questions based on their real condition, the result showed the students' internal factors and external factors that influence students' learning achievement. The questionnaire is done to analyze the factors which have been discussed above. The result of the test discussed to explain the condition internal factors and external factors of students. The result showed the factors category contribution in influencing students' learning achievement.

\footnotetext{
${ }^{10}$ Hudson, G. 2000. Essential introductory linguistics. Blackwell Publishers.
} 


\section{Research Paradigm}

A research paradigm is "the set of common beliefs and agreements shared between scientists about how problem should be understood and addressed". This research belongs to the constructivists/ interpretive paradigm. The constructivists believe that there is no single reality or truth, and therefore reality needs to be interpreted, and therefore they are more likely to use qualitative methods to get those multiple realities. This research used Double Paradigm by using 7 independent variables.

\section{Research Approach and Design}

This research describes how the students' factors influencing students' learning achievement. Descriptive method as simply the attempt to determine, describe or identify what is, while analytical research attempts to establish why it is that way or how it came to be. Three main purposes of descriptive studies can be explained as describing, explaining, and validating research findings.

\section{Research Findings}

The data in this research is questionnaire data that was given to the students in the form of factors that influence the students' learning achievement that sorted into motivation, attitude, personal practice, study habits, social factors, input and interaction of Ushuluddin, Adab and Da'wah students. There are 5 classes, consisted of 5 major in Ushuluddin, Adab and Da'wah Faculty, there are Islamic Communication and Broadcasting (Komunikasi dan Penyiaran Islam) consists of 25 students, Da'wah Management (Manajemen Dakwah) consists of 25 students, Islamic Guidance Counceling (Bimbingan Konseling Islam) consists of 20 students, Science of the Quran and Tafseer (Ilmu Al-Qur'an dan Tafsir) consists of 18 students and Study of Religions (Studi Agama- Agama) consists of 12 students in the academic year 2016/2017 at the second grade/semester. As for which is used as student achievement data that is from english subject score in the second semester. Before testing whether the motivation, attitude, personal practice, study habits, social factors, input and interaction affect the students' learning achievement in advance, the prerequisite test is tested linearity, regression significance and muticollinearity in the data obtained. 


\section{Discussion}

Based on the results of research and calculations that have been done, obtained the following results.

1. Motivation has significant effect to the students' learning achievement of Ushuluddin, Adab and Da'wah Faculty, Islamic State Institute of Pontianak. Motivation is the driving force of a person both from within and outside of themselves to achieve a success. The results obtained show the same thing according to the theory that says with the motivation, every students has the impetus to learn so that it can have a good learning achievement as well.

2. Attitude has no significat effect to the students' learning achievement of Ushuluddin, Adab and Da'wah Faculty, Islamic State Institute of Pontianak.

3. Personal practice has significant effect to the students' learning achievement of Ushuluddin, Adab and Da'wah Faculty, Islamic State Institute of Pontianak.

4. Study habits has significant effect to the students' learning achievement of Ushuluddin, Adab and Da'wah Faculty, Islamic State Institute of Pontianak.

5. Social factor has significant effect to the students' learning achievement of Ushuluddin, Adab and Da'wah Faculty, Islamic State Institute of Pontianak.
6. Input has significant effect to the students' learning achievement of Ushuluddin, Adab and Da'wah Faculty, Islamic State Institute of Pontianak.

7. Interaction has no significant effect to the students' learning achievement of Ushuluddin, Adab and Da'wah Faculty, Islamic State Institute of Pontianak.

\section{Bibliography}

Aqib, Z. 2002. Profesionalisme Guru dalam Pendidikan. Jakarta: Insan Cendikia.

Arikunto S. 2002. Prosedur Penelitian: Sebuah Pendekatan Praktek. Jakarta: Rineka Cipta.

Brown H.D. 1980. Principle of Language Learning and Teaching. San Francisco: Prentice Hall, Inc.

Brown J. 1988. Understanding Research in Second language Learning. New York: The Press Syndicate of the University of Cambrige.

Burden, R.Paul and Byrd, M. David. 1999. Methods for Effective Teaching. Needham Heights: Allyn \& bacon Company.

Carrotte, P. 1999. Teaching in Higher Education .Michigan: Michigan State University

Cohen L, Lawrence M and Keith. 2000 Research Method in Education, London: RoutledgeFalmer.

Dodigovic, M. 2005. Artificial Intelligence in Second Language Learning. Great Briatain: Cromwell Press Ltd.

Doughty C and Long M. 2005. The Handbook of second language 
acquisition. Maryland: Blackwell publishing.

Dörnyei, Z. 2003. Questionnaires in Second Language Research Construction Administration and Processing. London: Lawrence Erlbaum Associates Publishers.

Dörnyei, Z. 2005. The handbook of Second Language Acquisition. Nottingham: Blackwell Publisher. eISBN: 9781405132817.

Ellis, Rod. 1985. Understanding Second Language Acquisition. Oxford: Oxford UP.

Ellis, Rod. 1994. The Study of Second Language Acquisition. Oxford: Oxford UP.

Falk, J. 1978. Linguistics and language : A survey of basic concepts and implications (2nd ed.). John Wiley and Sons.

Hudson, G. 2000. Essential introductory linguistics. Blackwell Publishers.

Huo, C. 2006. How to Apply Humanistic Psychology to Establish an Effective Emotional Class in China.http://www.linguist.org.cn/d oc/Su (viewed 3 June 2010).

Johnson, B.J. 2006. Foreign Language Learning: An Exploratory Study on the External and Internal Influences Affecting Success. Thesis. Unpublished. Faculty of Baylor University.

Johnson, M. 2008. A Philosophy of Second Language Acquisition. London: Yale University Press

Jordan, Geoff. 2004. Theory Construction in Second Language Acquisition. Amsterdam/Philadelphia: John Benjamins Publishing Company.

Landsberger, J. Effective Habits for Effective Study. Available at: http://www.studygs.net/.htm

Accessed on: 21 April 2008.

Lee, Paoli. 2005. Students' Personality Type and Attitudes. Los Angeles: Catesol State Conference.

Phillips, M. 1998. Family background, parenting practices, and the blackwhite test score gap. The BlackWhite Test Score Gab, Washington, D.C.: Brooking Institution Press.

Reid, Gavin. 2007. Motivating Learners in The Classroom:Ideas and Strategies. London: Paul Chapman Publishing.

Rosenbusch, M. 1987. Foreign Language Learning and Children: The Parental Role.

http://www.eric.ed.gov/ERICDocs/ data/ericdos 2 sql/content_storage_0 1/0000019b/80/1c/33/1f.pdf (viewed 2 June 2010)

Setiyadi, A.B. 2006. Teaching English as A Second Language. Yogyakarta: Graha Ilmu.

Songsiri, Montha. 2007. An Action Research Study of Promoting Students' Confidence in Speaking English. The Doctorate of Education Thesis. Faculty of Arts, Education and Human Development Victoria University.

Sugiyono. 2008. Metode Penelitian Pendidikan (Pendekatan Kuantitative, Kualitative, dan $R \& D)$. Bandung: Alfabeta. 